\title{
МИР ДЕТСТВА И СПОСОБЫ ЕГО ВОПЛОЩЕНИЯ В ХУДОЖЕСТВЕННОМ ПРОИЗВЕДЕНИИ
}

\section{WORLD OF CHILDHOOD AND WAYS OF ITS PERSONALIZATION IN ARTISTIC WORKS}

N. Bykova

Summary: The article is devoted to the consideration of the features of the representation of the world of childhood in in fiction using the example of the story by I.S. Shmelyov «The Summer of the Lord». The world of childhood is represented in the images characteristic of an autobiographical work. Special attention is paid to images of native and significant people for the child, description of important events and details accompanying them. «The world of childhood» is revealed as a complex concept expressed by the means of the language picture of the world of the child. The study uses the contextual analysis method.

Keywords: autobiographical work, world of childhood, language picture of the world, child.

\author{
Быкова Наталья Николаевна \\ Аспирант, ФГБОУ ВО «Ивановский государственный \\ университет» \\ natkotk@mail.ru
}

Аннотация: Статья посвящена рассмотрению особенностей репрезентации мира детства в художественной литературе на примере повести И.С. Шмелёва «Лето Господне». Мир детства воплощён в образах, характерных для автобиографического произведения. Особое внимание уделяется образам родных и значимых для ребёнка людей, описанию важных событий и деталей, их сопровождающих. «Мир детства» раскрывается как сложное понятие, выраженное средствами языковой картины мира ребёнка. При исследовании используется метод контекстуального анализа.

Ключевые слова: автобиографическое произведение, мир детства, языковая картина мира, ребёнок.

ся к общению с отцом. Для главного героя повести «Лето Господне» время, проведённое с отцом, имеет большую ценность. Оно запоминается ребёнку надолго и вызывает положительные эмоции: «Я всё не верю, что поеду сейчас с отцом, - не верю и не верю, топчусь на месте, - может ли быть такая радость!» [7; 403] «С папашенькой на гулянье, такая радость!» [7; 422] Мать появляется в повествовании довольно редко: «Матушка со мной ласкова, называет - «великий постник» 7 ; 334]. Между детьми царят уважительные отношения. Старшая дочь воспринимается как помощница матери, учитель для младших детей: «А я так хорошо выучил, что Сонечка, старшая сестрича, похвалила, а она очень строгая» [7; 188].

В доме принимают многочисленных родственников, но родная тётка отца вызывает у домочадцев страх. О ней судят двояко: «Пелагея Ивановна ... су-рьёзная! <...> «немножко тово», и ее все боятся: всякого-то насквозь видит и говорит всего что-то непонятное и страшное» [7; 287]. Горкин почитает её за «юродную», которой открыта вся «тайная премудрость». Ребёнок перенимает от взрослых модель поведения с Пелагеей Ивановной: «И я её очень уважаю и боюсь попасться ей на глаза» [7; 287].

Для ребёнка важны не только члены его семьи, он с теплотой отзывается о людях, окружающих его. При этом используются слова с уменьшительно-ласкательными суффиксами или эпитеты, содержащие оценку: «старая моя нянька Домнушка» [7; 16], «милый Горкин» [7; 32], 
«Чего только не знает Горкин! Человек старинный, заповедный» [7; 205]. «Старый солдат Махоров, которого поцеловала пулька под Севастополем» [7; 392]. Для речевого поведения ребёнка характерно использование метафор и сравнений. Эта тенденция прослеживается в речи главного героя при описании им окружающих и самого себя: «на шее играют складочки, как гармонья» [7; 20], «а девицы в беленьких платочках, как птички чистенькие» [7; 384], «Вставать не хочется, а вспомнишь, что все говеют, - и делается легко, горошком вскочишь» [7; 333].

Не все знакомые вызывают уважение и любовь мальчика. Поход к крёстному всегда пугает ребёнка: «Я туда не люблю ходить: там гордецы-богачи, и крёстный грубый, глаза у него «какулюдоеда», огромный, чёрный, идёт - пол от него дрожит» [7; 311]. Среди гостей на празднике его отталкивает Надежда Тимофеевна «костлявая - худящая, похожая на Бабу-Ягу» [7; 436]. Мальчик выбирает для характеристик неприятных или пугающих его людей образы отрицательных сказочных персонажей.

Большое внимание в детской языковой картине мира главного героя уделяется колоративной лексике. Очень часто она входит в состав сравнений, метафор, передавая отношение говорящего к происходящему: «Схватываю охапку стружек, бросаю её кверху, - и сыплется золотистый, кудрявый дождь» [7; 120]. «Нет, душа у него чистая, как яичко» [7; 343]. Определённые цвета могут быть связаны с праздниками: «Небо до того чистое, зеленоватоголубое, - самое Богородичкино небо» [7; 71]. «Постилают голубую, рождественскую, скатерть и посуду ставят тоже парадную, с голубыми каёмочками» [7; 138]. «Золотой-голубой дьячок несёт огромное блюдо из серебра, красные на нём яблоки горою, что подошли из Курска» [7; 118]. «Из-под кремлёвской стены, розовато-седой с морозу, несут иконы, кресты, хоругви, и выходят серебряные священники, много-много» [7; 164]. Часть используемых прилагательных непосредственно называет цвет, например, красный, розовый, чёрный. Но есть «атрибуты, выражающие этот признак как относительный» [6; 552], т.е. в тексте присутствуют цветовые прилагательные, возникшие из относительных - золотой, серебряный: «Много серебряных священников» [7; 498]. Определённые цвета характерны, по мнению автора, для детства: «Приходят сны, лёгкие, розовые сны. <... > Лёгкие сны из розового детства» [7; 156]. Такие цвета, как зеленоватый, голубой, розовый, золотой, ассоциируются у Вани с радостью, спокойствием. Чёрный цвет часто не имеет негативной составляющей, он является обозначением большого скопления людей: «Далеко внизу ледяная дорожка в ёлках, гора, с чёрным пятном народа, и вьются фллаги» [7; 164]. «Над чернотой народа, покачиваются в блеске первые золотые хоругви» [7; 220]. «Улица черна народом» [7; 498]. В данных примерах «чернота народа» является лишь фоном, на котором выделяется то, что важно для внимания ребёнка.
Цвет в сознании главного героя содержит не только положительные коннотации. Негативную составляющую несут в себе несколько цветов. Часто мальчика отталкивает или даже пугает присутствие синего цвета: «И правда, шерсть на Стальной отливает всинь. «И черти тоже, говорят, синие!-хрипит кузнеи,-видать невидал, а сказывают бывалые» [7; 378]. «А эти, синие и зелёные, с тощими ногами и когтистыми лапами, рогами вперёд с заострёнными крыльями, каку огромной летучей мыши, <...>» [7; 486]. Даже в церкви синий цвет отталкивает Ваню: «У Распятия теплится синяя лампада, грустная» [7; 33]. Когда во время болезни отца зацвёл «змеиный цвет», его начали обходить все обитатели дома: «Все со страхом смотрели на него, какое синее жало из пасти свесилось, острое, такое, вот ужалит» [7; 449]. Жёлтый и белый (трансформируется в тексте в «бледный») цвета ассоциируется с болезнью, усталостью: «Все мы уж видели, что всё хуже и хуже: и худеет, и лицо желтеет, маленькое совсем стало, как яблочко» [7; 445], «лицо его стало совсем жёлтым» [7; 465], «лицо жёлтое, как лимон» [7; 471]. «Сказала матушка, бледная, усталая, с зажатым в руке платочком» [7; 465]. «И вижу желтеющее пятно на белом, глубоко вдавившееся в сморщившуюся подушку... - лицо? Маленькое какое, жёлтое!» [7; 492]. Цвет передаётся не только прилагательными и причастиями, но и существительными: «одной-то желчью» [7; 445]. Даже в момент наивысшего нервного напряжения (прощание с отцом) Ваня использует при описании Сергея Ивановича цветовую метафору: «и вижу восковую худую руку» [7; 492]. Но те же самые цвета в другом контексте вызывают у Вани положительные эмоции и приятные воспоминания: «грязь завалило белым снегом» [7; 275], «огромные жёлтики, как подсолнухи», «белые ромашки, величиной в тарелку» [7; 487].

Для детского восприятия цвет, свет, запах и звук неразрывно связаны друг с другом, и одно может порождать другое: «И запах совсем особенный, какой-то густой, зелёный, даже немножечко душно» [7; 106]. «Кисло трещат кузнечики, и кажется, что и от этого треска исходит свет - золотистый, жаркий» [7; 112]. «Пахнет последним летом, сухой горечью, яблочным свежим духом» $[7 ; 114]$. Само слово, по мнению главного героя, может содержать в себе цветовое или звуковое наполнение: «И ещё нравится новое слово «цело-мудрие» - будто звон слышится?» [7; 26]. «Рождество, <...>. Само слово это видится мне голубоватым» [7; 128].

В языковой картине мира Вани большое место занимают ольфакторная лексика. Запах сопровождает героя в разных ситуациях: встреча с отцом, сбор яблок, посещение кухни, выкуривание Масленицы. Практически всегда запах является приятным: «Незабвенный, священный запах. Это пахнет Великий пост» [7; 16]. «Стелется вязкий дух - тёплым печёным хлебом» [7; 28]. «Пахнет от него лошадью и сеном» [7; 89]. «Далеко слышен сладкий и 
острый дух, золотится везде соломкой» [7; 115]. Запах обязательный элемент, сопутствующий празднику. «Зеркально блестят паркетные полы, пахнущие мастикой с медовым воском, - запахом Праздника» [7; 297].

Ребёнок стремиться познать мир различными способами. Реальный мир сложен, многое в нём является загадкой для Вани. Поэтому он ищет сходство между ещё сложной для него реальностью и миром, который близок для любого ребёнка - миром сказочным. Ваня хочет найти в жизни то, о чём узнал из сказки: «Я с нетерпением ждал, что такое - живая вода. Знал сказку про «мёртвую» и «живую» воду. И тут так будет? ... чу-до?...» [7; 414]. Часто Ваня наделяет чертами сказочных героев людей, которые находятся рядом. Он представляет их в окружении атрибутов сказки: «Михал Иванов кажется мне особенным, лесовым, как в сказке. Живёт в избушке на курьих ножках, в глухом лесу, куда и дороги нет, выжигает уголь в какой-то яме, а кругом волки и медведи» [7; 342].

В языковой картине мира можно найти не только отражение действительности, но и передачу отношения к ней, чувств, ощущений, эмоций. Шарль Балли в своих исследованиях говорит о том, что мышление человека не может быть лишь эмоциональным или полностью рассудочным. «С одной стороны, верно, то, что мы никогда не думаем абсолютно рассудочно, но с другой стороны, эмоциональная доля мысли может быть настолько мала, что её речевое выражение практически следует зачислить в категорию логического языка» [1, с. 23]. А. Вежбицкая считает эмоциональность одной из особенностей русского языка. Ребёнок чаще, чем взрослый человек, демонстрирует свои эмоции, может рассказать о своих ощущениях. Именно поэтому на страницах повести «Лето Господне» часто встречается лексика, содержащая эмоциональный компонент. Детские эмоции разнообразны, они отображают различное состояние Вани: «светло у меня на душе, покойно», «мне теперь ничего не страшно» [7; 68]. Эмоции олицетворяются: "радостное что-то копошится в сердче», "радостное до слёз бьётся в моей душе» либо сравниваются с какимлибо явлением: «После моления радостней как будто стало, солнышком словно осветило» [7; 443]. Иногда эмоции смешиваются между собой, рождая неведомые до этого момента ощущения: «путается во мне и грусть, и радость» [7; 69], «с притаившейся радостью, которая смешалась с грустью, я выхожу из черкви» [7; 70], «мне радостно и жутко» [7; 125]. Иногда источник той или иной эмоции для ребёнка остаётся загадкой: «и радостно мне, и отчего-то грустно» [7; 100]. Но чаще всего ребёнок находит ей объяснение: «Пасха!... - и меня заливает радостью» [7; 353]. «И не мог больше говорить, страшно стало. - И все цветы у нас расцвели... и страшный змеиный цвет» [7; 449]. «Мне стало спокойно oт ласковых рук её» [7; 466]. «Эмоции могут порождать действие: «На душе у меня радостное и тихое, и хочется отчего-то плакать!» [7; 72]. В некоторых случаях эмоции не называются, но предмет, порождающий их, наделяется определённым свойством: «Что-то особенное около нас, невидимое и страшное» [7; 28] Заинтересованность Вани в чём-либо может выражаться на синтаксическом уровне с помощью перечисления, многосоюзия: «великопостный сахар, похожий на лёд зелёный и розовый, и красный, и лимонный» [7; 240].

Для детского возраста одним из ведущих видов деятельности является игра. П.Ф. Каптерев говорит о том, что игра - это «явление очень сложное, одновременно физическое и психическое» [3, с. 129]. В повести «Лето Господне» почти не встречается описаний игр и игрушек: «скачки», с тяжёлыми лошадками», «чёрный пистолет с медными пистонами», «матушка подарила краски», «мы стали бы играть вечером в лото и «скачки» [7; 464]. В повести описаны только два ребёнка, с которыми общается главный герой: Лёнька и Анюта. Ваню очень занимают дела, в которых участвуют взрослые: поездка на ледокольню, рубка капусты, сбор яблок. Ребёнок не стремиться быть взрослее, ему на самом деле интересны дела мира взрослых. Окружающие в некоторых случаях также приравнивают его к взрослым: «Нонче говеть будешь, уже отроча ... семь годков скоро» [7; 330].

В повести «Лето Господне» восприятие действительности во многом зависит от религиозности, которая поддерживается всеми обитателями дома. Само повествование разбивается на части в зависимости от церковных праздников: «Троицын день», «Рождество», «Пасха», или обрядов: «Благословение детей», «Соборование». От этого фактора во многом зависит и содержание ЯКМ ребёнка. Психолог В.В. Зеньковский видит в этом положительный момент: «Детские религиозные переживания непосредственны, музыкальны, неясны, но дитя ощущает мир как живое целое, которым руководит любовно и заботливо Отец» [2, с. 204].

Ваня читает и слушает церковные тексты, ему знакомы многие сюжеты и образы. Мальчик наделяет близких ему людей чертами святых: «Маленькое лицо, сухое, как у угодничков, с реденькой и седой бородкой, светиться, как иконка». «Такие - угодники бывают» [7; 16]. Сам он стремится быть похожим на Горкина: «надо намаслить голову, как Горкин» [7; 16]. При этом ребёнок способен увидеть в служителях церкви простых людей с определёнными привычками и недостатками, что выражается в использовании просторечной лексики: «Крестопоклонная, а он мочёные яблоки мякает... и живот у него какой, мамона! ... А он хряпает и хряпает» [7; 335].

Христианские законы, которым следует Ваня, отражаются не только в его лексиконе («ердань», «херувим», «стояние», «ефимоны» и др.), но и в поведении. Ребёнок стремится к безгрешной жизни: «И даю себе слово не ско- 
ромиться во весь пост» $[7 ; 18]$. Он способен признаться в собственных грехах: «Самый, пожалуй, страшный, как я в Чистый понедельник яичко выпил» [7; 336]. Вера помогает удержаться от необдуманных поступков: Ваня сдерживает себя от того, чтобы накричать в споре на Гришу и плюнуть в его сторону. Он вспоминает о том, что за каждым человеком стоит Ангел, которого тоже ранят чужие слова и действия. Мысли об этом помогают не только не совершить необдуманные действия, но и извиниться за уже сказанное. После этого Ване сразу становится легче:
«Я бегу-топочу по лестнице, и мне хорошо, легко» [7; 275].

В ходе изучения обозначенной темы можно говорить о том, что в повести И.С.Шмелёва «Лето Господне» показывается своеобразие восприятия мира, свойственного ребёнку. В детской языковой картине мира важное место занимает чувственный компонент восприятия окружающей действительности. Мир детства способен объединить в себе сказочные элементы с реалиями жизни, невозможное сочетается с возможным.

\section{ЛИТЕРАТУРА}

1. Балли Ш. Французская стилистика. Перевод с французского К. Долинина. Под редакцией Е.Г. Эткинда. Вступительная статья Р. Будагова. Серия: Лингвистическое наследие XX века. Москва : УРСС, 2001. 392 с.

2. Зеньковский В.В. Психология детства. Екатеринбург: Деловая книга, 1995. 348 с.

3. К Каптерев П.Ф. 0 природе детей: Избранное / Составители, вступительная статья М.В. Богуславский, К.Е. Сумнительный. М.: Издательский дом «Карапуз», 2005. 288c.

4. Мурадымова Е.Н. Иноязычная лексика родства в картине мира детского сознания // Вестник Ошского государственного университета. 2016. №3-2. C. 278-282.

5. Никитина Е.Ю., Тарасенко Е.В. Вопрос о детской языковой картине мира // Вестник Челябинского государственного педагогического университета. 2009. №5. C. 113-121.

6. Сальникова В.В. Колоративная лексика в языковой картине мира героев произведений С.Т. Аксакова «Детские годы Багрова-внука» и А.Н. Толстого «Детство Никиты» // Современные проблемы науки и образования. 2014. №2. С.552

7. Шмелёв И.С. Лето Господне. Москва : Детская литература, 2006. 527 с.

8. Щербина Л.С. Воспитание детей в русских традициях / Л.С. Щербина, Т.Т. Федосеенко, А.М. Берко [и др.] // Дошкольное образование: опыт, проблемы, перспективы развития : материалы Х Междунар. науч.-практ. конф. (Чебоксары, 29 окт. 2016 г.) / редкол.: 0.Н. Широков [и др.] Чебоксары : ЦНС «Интерактив плюс», 2016. С. 56-59.

(c Быкова Наталья Николаевна (natkotk@mail.ru). 